幼児期の身体動摇に視覚が及ぼす影響の動摇方向による差異

国分 充 ${ }^{1)} \cdot$ 葉石 光一2) $\cdot$ 奥住 秀之 ${ }^{2)}$

Difference of Visual Influences on Lateral

and Fore-aft Body Sway in Pre-school Children

Mitsuru Kokubun ${ }^{1)}$, Kouichi Haishi ${ }^{2)}$, Hideyuki Okuzumi ${ }^{2)}$

1) Faculty of Education, Kanazawa University

2) Graduate School of Education, Tohoku University

Research Fellow of the Japan Society for the Promotion of Science

The purpose of this study was to clarify the difference of visual influences on lateral and fore-aft body sway in pre-school children. The subjects were 67 children aged 3 to 6 years and 50 adults. Body sway was measured on a force platform in the Romberg position with the eyes open or shut. The RMS value for 512 points of $A / D$ converted data at $50 \mathrm{msec}$ intervals was calculated as an index of magnitude for each of the 2 types of directional sway.

(1) The RMS value of lateral sway was significantly higher with the eyes shut than with the the eyes open in 5-and 6-year-old children. The RMS value of fore-aft sway with the eyes open or shut did not differ obviously in the children tested. In adult subjects, the visual conditions had a great influence on both sway directions. The RMS value was significantly higher with the eyes shut.

(2) It was also found that under both visual conditions lateral sway showed a definite decrease with age, whereas fore-aft sway did not decrease in preschool children.

Key words: body sway, development, pre-school children, visual influences

はじめに

身体動摇のコントロールに視覚が重要な役割を 果していることはよく知られているが, 発達期に あってはその視覚による動摇のコントロールが十 分でないことを指摘する研究があり1)21，また， その影響は身体動摇の力向によって差異があるこ

1) 金沢大学教育学部

2) 東北大学大学院教育学研究科

日本学術振興会特別研究員
とを言らものもある3゙。しかし，これまでの研究 は分析時間や視覚情報の統制, 被験者の年榆や数 等に問題なしとせず, 発達期における視覚の影響 の動摇方向による差異はいまだ明確になっている とは言い難い。本研究は, 視覚の効果をもっとも 明確に検討乙える事態として，開眼と遮眼という 2 条件をもらけ，乙かも開眼条件にあっては視覚 情報について統制を加えて, 動摇方向に上る条件 の差が発達的にどのように変化するかを, 特に, 学童期以前の幼児を対象として調べた。幼児期は 
“explosion of skills”と言われる急激な運動発達 がなされる時期であり ${ }^{4}$ ，身体動摇にも大きな変 化があり得ると見られるのであるが，これまでの 研究では幼児が検討の対象となっている場合で も，ひとまとめされて処理されることが多く5)〜8)， 幼児期の身体動摇の変化の過程は明らかでない。

\section{方 法}

\section{1. 被験者}

心身ともに障害の存しない3・4 歳児 $(4.25 \pm$ 0.42 歳) 15 名 (男児 8 名, 女児 7 名), 5 歳児 (5. $42 \pm 0.25$ 歳) 39 名（男児25名，女児14名） 6 歳児 (6.25 0.17 歳) 13名（男児 7 名，女児 6 名），成 人（18～24歳）50名である。奻児は 1 つの幼稚園 に在籍する者で, 幼稚園の在籍児の全数調査を行 ったが，3・4歳の 2 名の者は，すぐに体を動か してしまったり，固視をほとんど行い得なかった りしたため，被験者から除いた。成人は大学生及 び大学院生である。

\section{2. 開眼時の視覚情報の統制}

開眼条件での測定の際に被験者の視覚情報を統 制するために，我々が設計した視覚刺激提示ボー ド9（図 1，川村鉄工所製（鉄製））を用いた。こ れは, 半径 $50 \mathrm{~cm}$, 高さ $180 \mathrm{~cm}(240 \mathrm{~cm}$ まで連続 可変) の半筒形のもので, 被験者がこのボードの 前に $30 \mathrm{~cm}$ 離九て立つと, 眼球を動かさない限 り均質な白色の視野が得られる。視覚情報として は，被験者の眼の高さにある固視点（視角 2 度） 之固視点から上下左右の視野限界まで広がる黒線 （線幅の視角 2 度）を与えた。つまり，固視点を 中心とする視野限界まで広がる十字形である。固 視点はボードに埋め込まれた玄関ドア用の来客確 認レンズで，これを通して被験者に気つかかるこ となく，被験者の様子を観察できる。こうして， 開眼条件の際の視覚情報を統制し，また，測定中 の被験者の固視の確認も可能となった。

\section{3 . 手続き}

重心動摇計 (平衡機能計：日本電気三栄製 IG06) を用い，その上で両足をそろえて（ロンベルグ足 位）できるだけ動かないで立つよう被験者に教示 し, 開眼条件, 遮眼条件（アイマスク使用）の順 に，ともに約60秒間測定を行った。そして，重心 動摇計から出力される左右動摇之前後動摇の他, 被験者が固視点より目をそらした時に観察者が手 に持ったスイッチにより入れるパルスの3つを磁

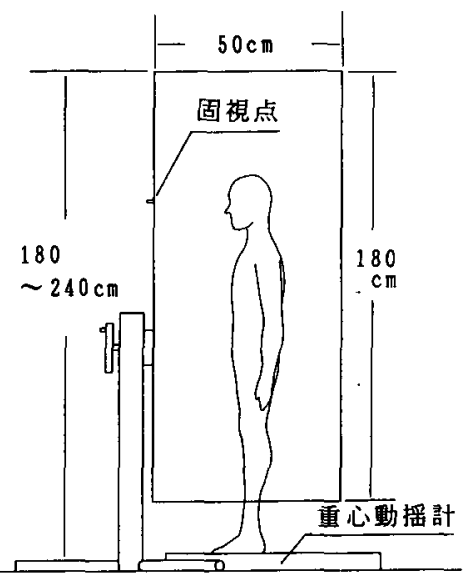

图 1 視覚刺激提示ボードと測定事態

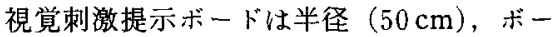
ド自体の高さ $(180 \mathrm{~cm})$ 及びその可変範囲 $(180 \sim 240 \mathrm{~cm})$ が書き入れてある。ボードは 固視点とりつけ位置が 3 力所あり，木た，八 ンドルを操作することにより高さが可変で， 被験者の眼の高さに固視点を調整することが できる。なお，人体は透視して描いてある。

気記録した（TEAC 製 XR710）。な和，開眼条件 においては，上に記したようにして被験者の固視 を監視し，固視点から目をとらした場合は固視を 続けるよら教示を繰り返した。

4. 分析

分析区間としては，固視点から目をそらした箇 所ができるだけ少ない連続した25.6秒間をとり， $10 \mathrm{~Hz}$ のローパスフィルタ（エヌェフブロック製 P83）を通した後, 左右, 前後の動摇方向ごとに サンプリング周波数 $20 \mathrm{~Hz}$ で $\mathrm{A} / \mathrm{D}$ 変換し，512ポ イント $(25.6$ 秒 $\times 20 \mathrm{~Hz}=512$ ポイント) のデジ タル值の標準偏差，すなわち RMS(Root Mean Square)值を算出し，動摇の大きさを表わす指標 とした。これは動摇の発達を方向別に検討してい るこれまでの研究2)3）にしたがったものである。 な拉，本報告で用いた上述の重心動摇計は出力と して，モメントと距離との二つが可能であるが， 本報告では計測対象の意味がより明瞭な距離出力 を選択した。

\section{結 果}

図 2 には左右動摇の, 図 3 には前後動摇の発達 的な変化を開眼, 遮眼条件を区別して示した。左 右動摇についてみると,標準偏差が大きいものの， 
開眼, 遮眼のいずれの条件でも発達的な動摇の減 少傾向が明らかである。開眼条件と遮眼条件では, 3，4歳ではその差がはっきりしないが， 5，6 歳 では開眼条件と遮眼条件での動摇の差が明瞭であ

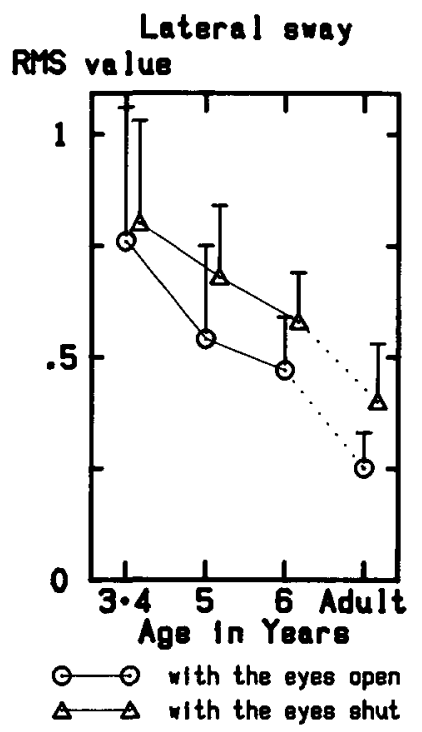

図 2 左右動摇の両視覚条件下での年齢的変化 各年齢での平均值及び標準偏差が記されてい る。

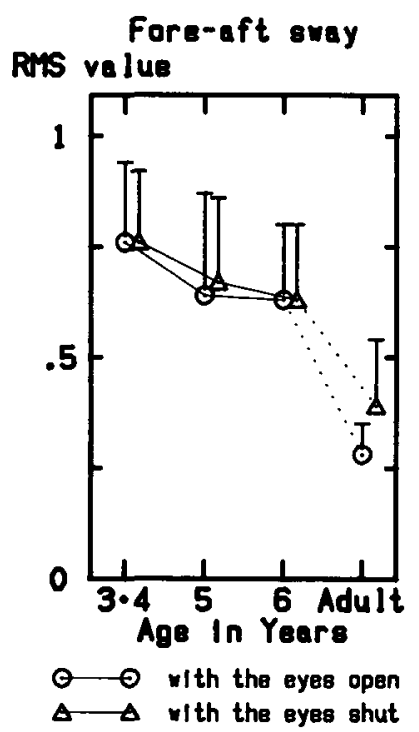

図 3 前後動摇の両視覚条件下での年跉的变化 各年龄での平均值及び標準偏差が記されてい る。
る。左右動摇に関して，年龄（成人を除く 3 群） と視覚条件を要因とする 2 要因の分散分析を行っ たところ，年齢，視覚条件のいずれにも有意な効 果が見られた（年齢： $\mathrm{F}_{2.64}=8.36, \mathrm{p}<0.005$ ，視 覚条件: $\left.\mathrm{F}_{1.64}=14.75, \mathrm{p}<0.005\right) 。 一$ 方, 前後動 摇についてみると，これも標準偏差が大きいが， 年齢的な動摇の減少傾向も, 開眼之遮眼条件の差 もはっきりしない。左右動摇の場合と同様に年榆 と視覚条件を要因とする2 要因の分散分析を行っ たところ, 年龄, 視覚条件のいずれにも有意な効 果はなかった（年齢: $F_{2.64}=2.74, p<0.1$, 視覚 条件: $\left.\mathrm{F}_{1.64}=0.1, \mathrm{p}>0.1\right)$ 。以上から, 幼児期に 执いて視覚の影響は左右動摇で顕著であり，また， 年齢的な動摇の減少も左右方向で明瞙であること がわかる。なお，成人の RMS 值は，いずれの方 向，いずれの条件でも，6歳のそれよりもかなり 小さく，特に前後動摇で 6 歳児との差が大きかっ た。また，開眼条件と遮眼条件の差も明瞭で（1 要因分散分析による [左右動摇: $\mathrm{F}_{1.49}=85.27$, $\mathrm{p}<0.005$, 前後動摇: $\left.\mathrm{F}_{1.49}=30.6, \mathrm{p}<0.005\right]$ ), 開眼条件での動摇の減少が明らかだった。

幼児の各年齢での RMS 值のばらつきは，図 2， 3 の各年秢の標準偏差に示されたように，いずれ の動摇方向でも大きかったのであるが，次に，幼 児の被験児一人一人について，それぞれの方向ご とに, ロンベルグ率([遮眼条件の RMS 值/開眼 条件の RMS 值]×100）を算出し，それを，(1)開 眼条件での RMS 值の增加が明らかな者 $(80 \%$ 末 満)，(2)開眼条件火遮眼条件の差がはっきりしな い者（80\%以上 $120 \%$ 未満），(3)開眼条件での RMS 值の減少が明らかな者（120\%以上）の 3 つに分け，年齢によって整理したものを表 $1 ， 2$ に示した。表中には, 対数線形モデル分析 ${ }^{10)}$ の 結果，有意に大きい，あるいは小さいとされた箇 所が記してある。これK基ついて，左右方向から 見ていくと（表 1)，全般的には，ロンベルグ率 が120\%を越える者が多い一方80\%に達しない者 は少なく，開眼条件での RMS 值の減少が明らか である者が多いことがわかる（最下段の総計）。 各年㛔についてみると，3，4歳では120\%を越兄 る者が少ないのに対し，5歳では80\%に達しない 者が少なく，ロンベルグ率は年㱓的に大きくなる 傾向がらかがわれる。そして，6歳では開眼条件 と遮眼条件の差がはっきりしない $80 \%$ から $120 \%$ 
表 1 年龄ごとに整理した左右動摇のロソベルグ率（人数）

\begin{tabular}{cccc}
\hline \hline 年粭 & $80 \%$ 未満 & $80 \%$ 以上 $120 \%$ 未満 & $120 \%$ 以上 \\
\hline $3 \cdot 4$ 歳 & 3 & 9 & $3^{\mathrm{S}}$ \\
5 歳 & $1^{\mathrm{S}}$ & 18 & 20 \\
6 歳 & 3 & $2^{\mathrm{S}}$ & 8 \\
\hline 計 & $7^{\mathrm{S}}$ & 29 & $31^{\mathrm{L}}$ \\
\hline
\end{tabular}

s：対数線形モデル分析で有意に小さいとされた䇢所

$\mathrm{L}$ : 対数線形モデル分析で有意に大きいとされた箇所

表 2 年齡ごとに整理した前後動摇のロンベルグ率（人数）

\begin{tabular}{cccc}
\hline \hline 年齢 & $80 \%$ 未満 & $80 \%$ 以上 $120 \%$ 未満 & $120 \%$ 以上 \\
\hline $3 \cdot 4$ 墄 & 2 & 11 & 2 \\
5 歳 & 8 & 20 & 11 \\
6 歳 & 4 & 7 & 2 \\
\hline 計 & 14 & $38^{\mathrm{L}}$ & 15 \\
\hline
\end{tabular}

${ }^{\mathrm{L}}$ : 対数線形モデル分析で有意に大きいとされた箅所

の者が少なくなっている。前後方向については(表 2)，統計的に有意とされたのは，ロソベルグ率 が80\%から120\%の者の, 全年齢を通しての総計 のみで，開眼条件と遮眼条件の差がはっきりしな い者が全般的に多いといらことがわかる。これは， 上に記した分散分析の結果を補強するものであ りこのことからも幼児期の身体動摇に対する視 覚の影響は左右動摇で顕著であると言うことがで きる。

\section{考察}

1. 測定条件について

一般に身体動摇の測定に呿いては，動かない上 らに被験者が意識的には努めている時の動摇にこ そ意味があり，教示に従って一定の時間同一姿勢 （すなわち，立位姿勢）を持続することが求めら れる。われわれも，被験者に対し，できるだけ動 かないよう，そして開眼条件では視標の固視も求 めた。教示に従ってある行動を持続することは, 子どもにとっては意外に困難なことで，そのこと は, 例えば, 課題として運動の持続を求めること になる Garfield ${ }^{11)} の$ motor impersistence test $の$ 年齢的な変化を調べた研究 ${ }^{12)}$ からも示唆される ところである。教示に従った運動の持続に密接に 関連しているとされるのが，言語による行動調整
で13)，これは言語のコミュニケーション機能及び

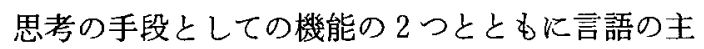
要な 3 機能のひとつとされ14) 16), 言語が行動を 調整していく手段となることを言う。そして，そ れと内的能力として対応するのが, 言語の意味的 側面に従って行動を企画し, 調整していく能力で ある行動調整能力である。行動調整能力は幼児期 に漸次的に発達すると言われ，その画期としては， 4 歳半が指摘されている14) 16)。したがって，こ れ以前の年龄を含む幼児を対象とした測定の場 合，それを上のような意味での身体動摇の測定と するには一般的にはきわめて困難であると言わざ るを得ない。これまでの身体動摇の発達に関する 研究で低年齢の幼児についての検討が十分でない ことや，また，直立検査が 4 歳以降で可能と言わ れる17)18）のも基本的にはこのことが関連してい るものと推測される。本報告では, 視覚刺激提示 ボードを用いることで, 開眼条件での視覚情報を 統制するとともに, 被験者の固視を監視し, 分析 区間む固視点から目をそらした箇所ができるだけ 少ない箇所を選び, 従来の研究より信頼性の高い 資料を収集することにつとめた。また，分析時間 に関しても, 測定自体は汪とんどの被験者で標準 的な測定時間とされる60秒は行ったものの，その 
すべてを分析時間とすると，年秢の低い幼児の場 合行動調整能力が未発達なために生じるアーチフ フクト（体動及び開眼条件の場合には固視持続困 難など）が少なからず混入し，長すぎると考光， 25.6秒とした。これは，また一方では，動摇の発 達を方向別に検討しているこれまでの研究でとら れている10秒 (Riach ら ${ }^{2)}$ ) や5秒 (Zernike ら ${ }^{3)}$ ) では, 被験者の安定した特徵といらには短すぎる と考えたこと，そして，後にFFTによる周波数 解析を行らことも考えたことにもよる（方法に記 したように25.6秒とすると，本報告でとったサン プリング周波数で512ポイントのデータが得られ， 2 のべき乗（9乗）となる)。幼児期を含さ身体 動摇の面積，距離の発達的変化を調べたこれまで の研究では19)，それらは年齢とともに減少してい くことが明らかとなっているが, 左右と前後動摇 の RMS 值を直交成分とするべクトルのノルムを 調べた結果は，これまでの知見と矛盾しない経年 的な単調減少傾向が明らかで20), この点において は, 本報告でとった方法手続き等は適当で, 妥当 な計測結果が得られていると考觉る。しかし，静 止姿勢を保持できず，すぐ動いてしまうとか，安 定した固視が汪とんど見られないために分析の対 象から除いた者が 3,4 歳で見られ, また, 分析 の対象となった者でも視標から目をそらした回数 を見ると， $3 ， 4$ 歳では一人当たり $3.1 \pm 4.3$ 回，5歳 $0.5 \pm 1.3$ 回, 6 歳 $0.5 \pm 0.8$ 回之 3,4 歳での行動 調整能力の未発達がうかがわれた。この点は, 特 に低年龄の者の身体動摇を評価し, そのメカニズ ムを考える上で十分な注意を払う必要がある。な 拉，本研究では，これまでの研究で言及されるこ とのある男女差についてなんら述べなかったが， これは本研究での被験者の数, 選び方ではそれを 問題とし得ないと考えたことによる。各年齢群の 男女の差は，方法に記したように5歳で男児が多 かったが対数線形モデル分析及び $\chi^{2}$ 検定のいず れによっても，統計的に有意なものではなかった ことを付言しておく。

2. 幼児期に打ける動摇方向による視覚の影響の 差異

はじめに述べたが, 身体動摇は, 一般に, 視覚 情報がある場合に減少することが知られている が，発達期にはそれが明らかでないことを言う研 究がある。例えば, Odenrickら1は子どもでは
開眼と閉眼の動摇面積の差が小さいことを指摘し， Riach ら²)は，9歳まではロンベルグ率が低く， 4 歳児にはロンベルグ率が100\%を下回る者も見 られることを指摘している。一方, 視覚情報のあ るなしではなく, 固視, 非固視の差異を調べた Zernicke ら ${ }^{3)}$ は，6歳及び10歳児について指標 の固視は前後動摇にはあまり影響せず, 左右動摇 の安定に効果があると, 動摇方向による差異を指 摘し，その理由として，平面上（前額面と平行） の視標は, 矢状面で起こる運動（動摇）より前額 面で起こる運動に関する情報を多く含んでいるこ とを挙げている。本報告は, 視覚情報のあるなし での比較を動摇方向別に行ったのであるが，その 結果は，成人では両方向ともに視覚情報により動 摇が小さくなるといらことが明らかであったが， 幼児期では， $3 ， 4$ 歳を除いて，視覚の影響は左 右動摇で顕著であるといらものであった。本報告 と同様に視覚情報のあるなしといら条件で方向別 の検討を幼児で行っているものに国分ら21)の研 究があるが，そこでも本研究と同様に左右方向で 視覚の影響が明瞭であることが指摘されている。 ただし，彼らが測定に用いている重心動摇計（日 本電気三栄製平衡機能計 IG02) は, 動摇のモ丸 ントを出力するもので, 動摇のモィントに関して 経年的に減少していくといら結果は得られて括ら ず（幼児期にはむしろ年齗とともに増加してい $る^{22)}$ ， その点で従来の身体動摇の発達に関寸る 知見と一般的には合致しないといら問題点を有し ている。

さて，万向により差が生じた要因としては，ま ず，Zernicke ら の)の言らような提示した視覚刺 激がもつ動摇方向との関保での情報の多少という ことを, 視知覚発達と関連させて考える必要があ ろら。すなわち, 幼児期には奥行知覚の発達が不 十分で, 前後方向の動摇の視覚的感知が十分なさ れず，そのため，前後方向の動摇に対する開眼の 影響は奻児期には明瞭でなく，一方，成人では十 分な奥行知覚が成立しているため，どちらの動摇 方向でも開眼化よって動摇が減少すると考爷るこ とができる。細かな奥行の知覚は漠然とした奥行 の知覚に比してかなり遅れて発達すると言われて 扣り23),この点との関連の追求が必要である。

こうした視知覚の発達とともに，足位について の検討も必要である。本報告ではロンベルグ足位 
をとらせたが，これは両足を離す足位よりも支持 基底面が狭くなるため, 力学的には左右方向に動 摇しやすい姿勢となる。このような力学的な姿勢 構成の問題と視覚的影響の動摇方向による違いが どのよらに関係しているかを，足位を変えて検討 する必要がある。

さらに, 先に述べた行動調整能力の問題も勘案 する必要があろう。特に， $3 ， 4$ 歳ではいずれの 方向に関しても開眼条件と遮眼条件との間に差が 見られなかったことについては，本来的に視覚が 姿勢の安定化を妨げるのではなく，行動調整の不 十分さによって差が明らかにならないといら可能 性も考兵得る。すなわち, 開眼条件では, 視覚情 報を統制したとはいっても遮眼条件と比較した時 には，子どもが定位し得る刺激は多く，行動調整 能力が未発達であるためそうした副次的な刺激に 反応し，それに伴って身体を動かした結果動摇が 大さくなった可能性も考光得る。な扣，幼児の身 体動摇とともに眼球運動を記録したRiach5 24) は，低年秢の幼児では固視を求めた場合のサッ ケード（すなわち，固視点から目をとらすこと） が多いことを指摘し，成人でサッケードが身体動 摇に対して安定化の効果を有するとする研究25) があることから，それが動摇の安定化のために生 じている可能性も考えているが，固視点から目を そらすことを意味するサッケードは行動調整能力 の未発達と結びついていると見るのが自然である 5 。

3. 幼児期に特ける動摇方向による発達傾向の差 異

前後, 左右の動摇方向ごとの発達の様相に関し ては, 左右方向については, 開眼条件, 遮眼条件 ともに経年的な動摇の減少傾向が明瞭であった が，前後方向でははっきりしなかった。これは， 両条件で，すなわち遮眼条件でも見られたことか ら, 視覚系の発達以外の要因が関与していると考 えられる。それらの中では, 迷路系, 体性感覚系 等の感覚系の身体の左右軸と前後軸とでの発達差 や，身体構造 (骨, 勒帯等) の成熟の, 左右軸之 前後軸の差異等が重要であろう。本報告の結果か らは, 幼児期には, 身体の左右軸に係る構造及び 機能の成熟発達がなされ，一方，成人では前後方 向の動摇の減少が左右方向より明瞭であることか ら，本報告が対象とした年跉期より後で成人に向
かって前後軸に係る構造及び機能の成熟発達がな されることが示唆される。

身体動摇は, 発達期に打いて減少傾向にあるこ そがよく知られているが，そのメカニズムは十分 明らかではない。それを，身体動摇に係る諸構造 及び機能系の単調的, 並行的な発達に伴弓ものと 考える他に, 視覚・迷路・体性感覚等の感覚系や 身体構造の成熟といった複数の要因が消長するダ イナミックな過程と考光ることもできる。そのよ らなダイナミックな身体動摇の発達メカニズムを 考えていく時に，身体動摇の方向に上る差異を見 ていくことは，それと身体構造及び動摇の調節に 係る諸感覚系の方向性や成熟発達に伴らそれらの 方向性の変化とを関連させて考えることにより， きわめて有用な視座になるものと思われる。

\section{まとめ}

幼児期の身体動摇に視覚が及湆す影響の動摇方 向による差異を明らかにするために，3，4 歳か ら 6 歳までの幼児 67 名, 成人50名を対象として, 開眼及び遮眼の 2 条件で身体動摇を測定し, 左右, 前後の動摇方向別に RMS 值を算出し，それを指 標に条件間の差異及び動摇の年齢的変化を調べ た。その結果, 幼児期に扣いて, 条件間の差は, 左右動摇では， 3,4 歳を除いて, 明瞭で, 開眼 条件での動摇の減少が顕著であったが，前後方向 でははっきりした差は見られなかった。また，年 㱓的な動摇の減少傾向も左右方向では両条件とも に明暸であったが，前後方向でははっきりしなか った。成人では，いずれの方向でも，開眼条件と 遮眼条件の差が明瞭で, 開眼条件での動摇の減少 が明らかだった。

\section{付 記}

平素よりご指導頂いている東北大学名誉教授松 野豊先生 (現東北芸術工科大学教授), 茨城大学 教授鈴木宏哉先生，また，波形処理を手汇どき下 さっている東京学芸大学講師小池敏英先生に深く 感謝致します。測定の際には浦和市松本幼稚園の 園児の皆さん，諸先生方に多大なるご協力を頂き， 測定の段取りでは長野大学助教授細㴊富夫先生の 手を煩わせた。記して謝意を表します。

なお, 本研究の一部は, 科学研究費補助金に拠 った（平成 $5-6$ 年度一般研究 C 課題番号 05680204)。 


\section{文 献}

1) Odenrick P, Sandstedt P: Development of postural sway in the normal child. Human Neurobiol 3: 241-244, 1984

2 ) Riach CL, Hayes KC: Maturation of postural sway in young children. Develop Med Child Neurol 29: 650-658, 1987

3) Zernicke RF, Gregor RJ, Cratty BJ: Balance and visual proprioception in children. $\mathrm{J}$ Human Mov Studies 8: 1-13, 1982

4) Cratty BJ: Perceptual and motor development in infants and children (3rd ed). Prentice-Hall, New Jersey, 1986

5) 平林千春, 田口喜一郎: 小児の発育伴う重 心動摇の定量的変動. Equilibrium Res 44: 252-256, 1985

6）柳田三洋子：小児のめむい平衡障害に関する 研究 第一編 学童検診における平衡障害の 調查. Equilibrium Res 45: 175-188, 1986

7 ）柳田三洋子：小児のめまい平衡障害に関する 研究 第二編 健常小児の重心動摇. Equilibrium Res 45: 332-344, 1986

8 ）坂口正範：小児の重心動摇および頭部動摇の 年齢的変動. Equilibrium Res 48: 341-350， 1989

9）奥住秀之：精神遅帯児・者の身体重心動摇と 視覚情報の利用のあり方との関連に関する研 究. 平成 3 年度科学研究費補助金 (一般研究 B「精神羊漁児のバランス障害の要因々障害 克服のための指導に関する研究」）研究成果 報告書（研究代表者松野豊）：79-87, 1992

10）弓野憲一：分割表を吟味する一対数線形モデ 几分析一. 海保博之編著. 心理・教育データ の解析法10講応用編. 77-97頁, 福村出版, 東京, 1986

11) Garfield JC: Motor impersistence in normal and brain-damaged children. Neurol 14: 623630,1964

12）北原 佶, 松井 晨, 松島昭広, 他: 運動発 達からみた soft neurological signs. 脳と発達
9: 34-46, 1977

13）渡辺弘純: 言語の行動調整機能の発達と行動 の持続の関係について. 愛媛大学教育学部紀 要 27: 61-72, 1981

14）ルリヤ アェル 編著 : 精神薄弱児（山口 薑, 斉藤義夫, 松野豊, 他訳). 157-174, 三 一書房, 1962

15）ルリヤ ア エル：人間の脳と心理過程（松 野豊訳).129-164，金子書房, 1976

16）ルリヤアェル：言語と精神発達(松野豊. 関口昇訳).166, 明治図書, 1969

17）道下和美 : 小児の平衡機能検查法. 耳鼻臨床 64: 1056-1060, 1971

18）柳田三洋子：小児のめまい平衡障害に関する 研究 第三編 小児のめまい平衡障害症例. Equilibrium Res 45: 345-357, 1986

19）小島幸枝, 竹森節子: 小児の身体平衡の発達 について．耳鼻臨床 73: 865-871，1980

20）奥住秀之, 葉石光一, 国分 充: 身体動摇の 大きさと方向性の発達的変化. 発達科学研究 年報 $7: 37-42,1993$

21）国分 充，葉石光一，奥住秀之：身体動摇の 発達的变化汇関する一考察. 金沢大学教育学 部紀要（教育科学編）42:11-14, 1993

22）国分 充: 身体動摇の方向に関する発達的变 化. 第61回発達科学研究交流会報告, 1993

23）古崎愛子：知覚の発達. 和田陽平, 大山正, 今井省吾編著. 感覚・知覚ヘンドブック. 105頁，誠信書房， 1969

24) Riach CL, Starkes JL: Visual fixation and postural sway in children. J Mot Beh $21: 265$ $-276,1989$

25) Uchida $T$, Hashimoto $M$, Suzuki $N$, et al: Effects of peripheral saccades on the body sway in human subjects. Neurosci Lett 13: 253-258, 1979

$\left(\begin{array}{l}\text { 原稿到着 : 平成 } 5 \text { 年12月 } 8 \text { 日 } \\ \text { 別刷請求先 : 国分 充 } \\ \text { 个920-11 金沢市角間町 } \\ \text { 金沢大学教育学部 }\end{array}\right)$

